\title{
Heracleum moellendorffii roots inhibit the production of pro-inflammatory mediators through the inhibition of NF-KB and MAPK signaling, and activation of ROS/Nrf2/HO-1 signaling in LPS-stimulated RAW264.7 cells
}

Ha Na Kim¹, Jeong Dong Kim¹, Joo Ho Yeo', Ho-Jun Son², Su Bin Park', Gwang Hun Park², Hyun Ji Eo ${ }^{2}$ and Jin Boo Jeong ${ }^{1,3^{*}}$ (B)

\begin{abstract}
Background: Heracleum moellendorffii roots (HM-R) have been long treated for inflammatory diseases such as arthritis, backache and fever. However, an anti-inflammatory effect and the specific mechanism of HM-R were not yet clear. In this study, we for the first time explored the anti-inflammatory of HM-R.

Methods: The cytotoxicity of HM-R against RAW264.7 cells was evaluated using MTT assay. The inhibition of NO and $\mathrm{PGE}_{2}$ production by HM-R was evaluated using Griess reagent and Prostaglandin $E_{2}$ ELISA Kit, respectively. The changes in mRNA or protein level following HM-R treatment were assessed by RT-PCR and Western blot analysis, respectively.

Results: HM-R dose-dependently blocked LPS-induced $\mathrm{NO}$ and $\mathrm{PGE}_{2}$ production. In addition, HM-R inhibited LPSinduced overexpression of iNOS, COX-2, IL-1 3 and IL-6 in RAW264.7 cells. HM-R inhibited LPS-induced NF-KB signaling activation through blocking IKB-a degradation and p65 nuclear accumulation. Furthermore, HM-R inhibited MAPK signaling activation by attenuating the phosphorylation of ERK1/2, p38 and JNK. HM-R increased nuclear accumulation of Nrf2 and HO-1 expression. However, NAC reduced the increased nuclear accumulation of Nrf2 and HO-1 expression by HM-R. In HPLC analysis, falcarinol was detected from HM-R as an anti-inflammatory compound.
\end{abstract}

Conclusions: These results indicate that HM-R may exert anti-inflammatory activity by inhibiting NF-KB and MAPK signaling, and activating ROS/Nrf2/HO-1 signaling. These findings suggest that HM-R has a potential as a natural material for the development of anti-inflammatory drugs.

Keywords: Anti-inflammation, Heracleum moellendorffii, Inflammatory diseases, Inflammatory response

\footnotetext{
* Correspondence: jjb0403@anu.ac.kr

${ }^{1}$ Department of Medicinal Plant Resources, Andong National University,

Andong 36729, Republic of Korea

${ }^{3}$ Insititute of Agricultural Science and Technology, Andong National

University, Andong 36729, Republic of Korea

Full list of author information is available at the end of the article
}

(c) The Author(s). 2019 Open Access This article is distributed under the terms of the Creative Commons Attribution 4.0 International License (http://creativecommons.org/licenses/by/4.0/), which permits unrestricted use, distribution, and reproduction in any medium, provided you give appropriate credit to the original author(s) and the source, provide a link to the Creative Commons license, and indicate if changes were made. The Creative Commons Public Domain Dedication waiver (http://creativecommons.org/publicdomain/zero/1.0/) applies to the data made available in this article, unless otherwise stated. 


\section{Background}

Macrophages, known as one of the immune cells, secrete a variety of pro-inflammatory mediators such as nitric oxide $(\mathrm{NO})$, prostaglandin $\mathrm{E}_{2}\left(\mathrm{PGE}_{2}\right)$, inducible nitric oxide (iNOS) and cyclooxygenase-2 (COX-2), as well as pro-inflammatory cytokines including interleukin-1 $\beta$ (IL-1 $\beta$ ), interleukin-6 (IL-6), and tumor necrosis factor- $\alpha$ (TNF- $\alpha$ ) [1]. The appropriate cytokine secreted by macrophages acts to protect the body from external harmful factors, but excessive cytokines are known to cause chronic inflammation associated with inflammatory human diseases such as atheriosclerosis, arthritis, cardiovascular disease and other deadly diseases [2, 3]. Therefore, regulation of pro-inflammatory cytokines and mediators has been regarded as complementary strategy to the inflammatory human diseases.

Heracleum moellendorffii Hance (H. moellendorffii) growing in the field and mountains of Korea, China and Japan has been used as edible wild herb in Korea [4]. $H$. moellendorffii leaves have been reported to exert detoxification, antioxidant and anti-melanogenic activities [4-6] and $H$. moellendorffii roots have been used as traditional herbal medicine treating inflammatory human diseases such as arthritis, backache and fever [4]. In a previously reported study of the anti-inflammatory activity of $H$. moellendorffii, dehydrogeijerin isolated from $H$. moellendorffii leaves has been reported to block the expression of the pro-inflammatory mediators via the inhibition of MAPK signaling activation [7]. However, there is no studies on the anti-inflammatory activity and its potential mechanism of $H$. moellendorffii roots. In this study, we aimed to investigate anti-inflammatory activity of $H$. moellendorffii roots in LPS-stimulated RAW264.7 cells, and to elucidate the potential mechanism.

\section{Methods}

\section{Materials}

3-(4,5-dimethylthiazol-2-yl)-2,5-diphenyltetrazolium bromide (MTT), tolfenamic acid (TA), N-Acetylcysteine (NAC) and LPS were purchased from Sigma Aldrich (St. Louis, MO, USA). Antibodies against IкB- $\alpha$, p65, phospho-ERK1/ 2, ERK1/2, phospho-p38, p38, phospho-JNK, JNK, HO-1, $\mathrm{Nrf} 2, \beta$-actin and TBP were purchased from Cell Signaling (Bervely, MA, USA).

\section{Sample preparation}

After H. moellendorffii (voucher number: FMCHm-20190521-001 003) was collected and identified by Forest Medicinal Resources Research Center, National Institute of Forest Science (Yongju, Korea), H. moellendorffii was generously provided. Twenty gram of $H$. moellendorffii roots was immersed in $400 \mathrm{ml}$ of $70 \%$ ethanol and then extracted for $72 \mathrm{~h}$ with stirring at room temperature. After $72 \mathrm{~h}$, the extracts were filtered and concentrated using a vacuum evaporator and then lyophilized. The ethanol extracts of $H$. moellendorffii roots (HM-R) were stored $80^{\circ} \mathrm{C}$ until use. HM-R was dissolved in dimethyl sulfoxide (DMSO) before the experiment to treat the cells. DMSO was used as a control in all experiments and the concentration of DMSO treated in the cells did not exceed $0.1 \%$ $(\mathrm{v} / \mathrm{v})$.

\section{Cell culture}

RAW264.7 cells (American Type Culture Collection, Manassas, VA, USA) were maintained at $37{ }^{\circ} \mathrm{C}$ under a humidified atmosphere of $5 \% \mathrm{CO}_{2}$ using Modified Eagle medium (DMEM)/F-12 1:1 Modified medium (Lonza, Walkersville, MD, USA) containing $10 \%$ fetal bovine serum, $100 \mathrm{U} / \mathrm{ml}$ penicillin and $100 \mu \mathrm{g} / \mathrm{ml}$ streptomycin.

\section{Cell viability assay}

The cytotoxicity of HM-R against RAW264.7 cells was evaluated using MTT assay. After the cells $\left(3 \times 10^{3}\right.$ cells/ well) were plated on a 96-well plate for $24 \mathrm{~h}, \mathrm{HM}-\mathrm{R}$ was applied to the cells for $24 \mathrm{~h}$. Then, $50 \mu \mathrm{l}$ of MTT solution $(1 \mathrm{mg} / \mathrm{ml})$ was added to the cells and incubated for $2 \mathrm{~h}$. Then, cell culture supernatants were removed and DMSO was added to the cells. The absorbance was measured at $570 \mathrm{~nm}$ using UV/Visible spectrophotometer (Human Cop., Xma-3000PC, Seoul, Korea).

\section{$\mathrm{NO}$ and $\mathrm{PGE}_{2}$ determination}

RAW264.7 cells $\left(1 \times 10^{5}\right.$ cells/well $)$ in 12 -well plate for $24 \mathrm{~h}$ were pretreated with HM-R for $2 \mathrm{~h}$ and co-treated with LPS $(1 \mu \mathrm{g} / \mathrm{ml})$ for $18 \mathrm{~h}$. After the treatment, the cell culture supernatants were collected for the analysis of $\mathrm{NO}$ and $\mathrm{PGE}_{2}$ production. For measurement of NO production, the cell culture supernatants and Griess reagent (Sigma Aldrich) were mixed at a 1:1 ratio and reacted at the room temperature for $15 \mathrm{~min}$, and the absorbance was measured at $540 \mathrm{~nm}$ using UV/Visible spectrophotometer (Human Cop., Xma-3000PC, Seoul, Korea). PGE 2 production was analyzed using Prostaglandin $\mathrm{E}_{2}$ ELISA Kit (Cayman Chemical, Ann Arbor, MI, USA) according to the manufacturer's protocols.

\section{Isolation of nuclear fraction}

After the treatment, nuclear protein from RAW264.7 cells was isolated using a Nuclear Extract Kit (Active Motif, Carlsbad, CA, USA) according to the manufacturer's protocols. The isolated nuclear protein was stored at $-80^{\circ} \mathrm{C}$ until analysis.

\section{SDS-PAGE and Western blot analysis}

To extract protein from RAW264.7 cells, RAW264.7 cells were washed three times with cold $1 \times$ phosphate-buffered saline and lysed at $4{ }^{\circ} \mathrm{C}$ for $30 \mathrm{~min}$ using cold radioimmunoprecipitation assay buffer (Boston Bio Products, Ashland, 
MA, USA) containing protease inhibitor (Sigma-Aldrich) and phosphatase inhibitor (Sigma-Aldrich). After centrifugation at 15,000 rpm for $10 \mathrm{~min}$, the supernatant was recovered for protein quantitation using BCA protein assay (Thermo Fisher Scientific, Waltham, MA USA). The protein was separated on SDS-PAGE for about $1 \mathrm{~h}$ at $150 \mathrm{~V}$ and subsequently transferred to PVDF membrane (Bio-Rad Laboratories, Inc., Hercules, CA, USA) for $2 \mathrm{~h}$ at $100 \mathrm{~V}$. After blocking the PVDF membranes using 5\% non-fat dry milk in tris-buffered saline containing $0.05 \%$ Tween 20 (TBS-T) by stirring at room temperature for $1 \mathrm{~h}$, the specific primary antibodies in 5\% non-fat dry milk dissolved with TBS-T buffer were treated with PVDF membranes and reacted with stirring at $4{ }^{\circ} \mathrm{C}$ overnight. Then, PVDF membranes were washed three times with TBS-T buffer, and then treated with the secondary antibodies in 5\% nonfat dry milk dissolved with TBS-T buffer for $1 \mathrm{~h}$ at room temperature. Chemiluminescence was detected with ECL Western blotting substrate (Amersham Biosciences, Piscataway, NJ, USA) and visualized using LI-COR C-DiGit Blot Scanner (Li-COR Biosciences, Lincoln, NE, USA).

Reverse transcriptase-polymerase chain reaction (RT-PCR) RNA isolation from RAW264.7 cells and cDNA synthesis from isolated RNA were performed using a RNeasy Mini Kit (Qiagen, Valencia, CA, USA) and a Verso cDNA Kit (Thermo Scientific, Pittsburgh, PA, USA) according to the manufacturer's protocol, respectively. PCR was performed using PCR Master Mix Kit (Promega, Madison, WI, USA). The sequence of specific primers used for PCR analysis was as follows: iNOS: forward 5 '-ttgtgcatcgacctaggctggaa$3^{\prime}$ and reverse $5^{\prime}$-gacctttcgcattagcatggaagc-3', COX-2: forward $5^{\prime}$-gtactggctcatgctggacga- 3 ' and reverse $5{ }^{\prime}$-caccatacactgccaggtcagcaa-3', IL-1 $\beta$ : forward $5^{\prime}$-ggcaggcagtatcactcatt-3' and reverse $5^{\prime}$-cccaaggccacaggtattt-3', IL-6: forward $5^{\prime}$-gaggataccactcccaacagacc- $3^{\prime}$ and reverse $5^{\prime}$-aa gtgcatcatcgttgttcataca-3'; GAPDH: forward 5' -ggactgtggtc atgagcccttcca- $3^{\prime}$ and reverse $5^{\prime}$-actcacggcaaattcaacggcac3'. The PCR bands were visualized using agarose gel electrophoresis.

\section{NF-KB luciferase activity}

Transient transfection was performed using the PolyJet DNA transfection reagent (SignaGen Laboratories, Ijamsville, MD, USA) according to the manufacturer's protocol. Briefly, NF-kB luciferase construct (Addgene, Cambridge, MA, USA, $1 \mu \mathrm{g} /$ well), pRL-null vector $(0.1 \mu \mathrm{g} /$ well) and PolyJet DNA transfection reagent were mixed for $15 \mathrm{~min}$ at room temperature. RAW264.7 cells were treated with the mixtures and incubated for $24 \mathrm{~h}$. The measurement of NF- $\mathrm{kB}$ luciferase activity was performed using a dual-luciferase assay kit (Promega, Madison, WI, USA). pRL-null luciferase activity was used to normalize NF-kB luciferase activity.

\section{Analysis of bioactive components}

The analysis of anti-inflammatory compounds from HM-R was performed using HPLC. In HPLC analysis, Waters 1525 system with a Waters 2487-dual $\lambda$ absorbance detector was used. The column was equipped with the Waters SPHERISORB $10 \mu \mathrm{m}$ Silica $(250 \mathrm{~mm} \times 4.6$ $\mathrm{mm})$. The mobile phase consisted of $10 \%$ ethanol and $90 \%$ hexane. The flow rate was kept constant at $1.0 \mathrm{ml} /$ min for a total run time of $10 \mathrm{~min}$. The injection volume of HM-R was $10 \mu \mathrm{l}$. The elution was monitored at 254 nm.

\section{Statistical analysis}

All the data are shown as mean \pm SD (standard deviation). Statistical analysis was performed with one-way ANOVA followed by Dunnett's test. Differences with "P or $\# P<0.05$ were considered statistically significant.

\section{Results \\ HM-R inhibits LPS-mediated overproduction of $\mathrm{NO}$ and $\mathrm{PGE}_{2}$ in RAW264.7 cells}

HM-R reduced NO production by $20.3 \%$ at $12.5 \mu \mathrm{g} / \mathrm{ml}$, $56.0 \%$ at $25 \mu \mathrm{g} / \mathrm{ml}$ and $88.4 \%$ at $50 \mu \mathrm{g} / \mathrm{ml}$ in LPSstimulated RAW264.7 cells, respectively (Fig. 1a). It was also observed that HM-R inhibited LPS-induced overproduction of $\mathrm{PGE}_{2}$ by $11.3 \%$ at $12.5 \mu \mathrm{g} / \mathrm{ml}, 37.6 \%$ at $25 \mu \mathrm{g} / \mathrm{ml}$ and $58.7 \%$ at $50 \mu \mathrm{g} / \mathrm{ml}$ in RAW264.7 cells (Fig. 1b). We compared the inhibitory effect of HM-R against NO production with TA as one of the nonsteroidal anti-inflammatory drugs (NSAIDs) in LPSstimulated RAW264.7 cells. As shown in Fig. 1c, 25 rg/ $\mathrm{ml}$ of HM-R showed similar inhibitory activity against LPS-mediated NO production compared to $12.5 \mu \mathrm{g} / \mathrm{ml}$ of TA. To investigate whether the inhibitory activity of HM-R was resulted from its cytotoxicity, the effects of HM-R on cell viability in RAW264.7 cells were measured using the MTT assay. HM-R did not affect cytotoxicity on RAW264.7 cells (Fig. 1d).

\section{HM-R inhibits LPS-mediated overexpression of pro- inflammatory mediators such as iNOS, COX-2, IL-1 $\beta$ and IL-6 in RAW264.7 cells}

In inflammatory response, the production of $\mathrm{NO}$ and $\mathrm{PGE}_{2}$ is regulated by the expression of iNOS and COX2 , respectively $[8,9]$. Thus, we investigated the effect of HM-R on the expression of iNOS and COX-2 in LPSstimulated RAW264.7 cells. As shown in Fig. 2, overexpression of iNOS and COX-2 was observed in the cells treated with LPS alone. However, HM-R has been shown to effectively inhibit the overexpression of iNOS and COX-2 induced by LPS. In addition, macrophages produce large amounts of inflammatory cytokines such as IL-1 $\beta$ and IL- 6 that cause chronic inflammation when inflammatory response occurs [10]. Thus, we evaluated 
(A)

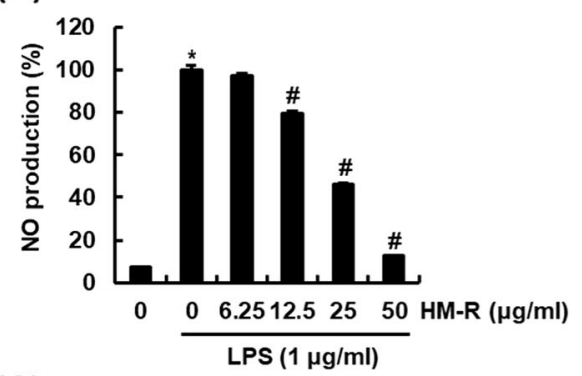

(C)

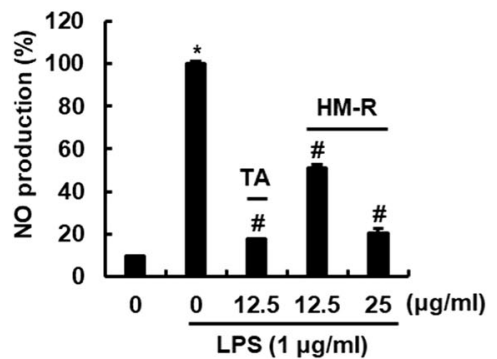

(B)

(D)
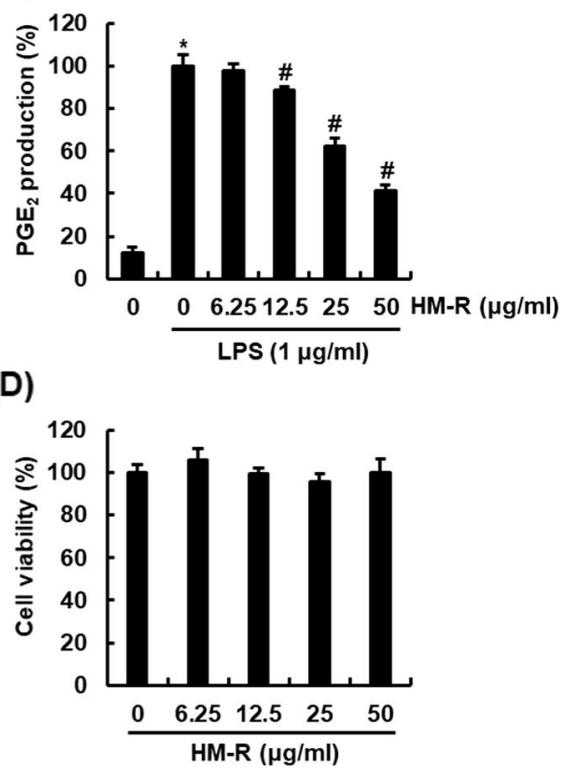

Fig. 1 Inhibitory effect of HM-R against NO and PGE $E_{2}$ production in LPS-stimulated RAW264.7 cells. a and $\mathbf{b}$ RAW264.7 cells were pretreated with HM-R for $2 \mathrm{~h}$ and then co-treated with LPS $(1 \mu \mathrm{g} / \mathrm{ml})$ for $18 \mathrm{~h}$. NO and PGE 2 production was measured by Griess assay and Prostaglandin $\mathrm{E}_{2}$ ELISA Kit, respectively. c RAW264.7 cells were pretreated with HM-R or TA for $2 \mathrm{~h}$ and then co-treated with LPS (1 $\mathrm{\mu g} / \mathrm{ml})$ for $18 \mathrm{~h}$. NO production was measured by Griess assay. d RAW264.7 cells were treated with HM-R for $24 \mathrm{~h}$. Cell viability was measured by MTT assay. ${ }^{*} P<0.05$ compared to the cells without the treatment, and ${ }^{\#} P<0.05$ compared to the cells treated with LPS alone

the inhibitory effect of HM-R against LPS-induced overexpression of IL-1 $\beta$ and IL-6. As a result (Fig. 2). HM-R dose-significantly suppressed the mRNA expression of IL-1 $\beta$ and IL-6 in LPS-stimulated RAW264.7 cells. Considering the inhibitory effect of HM-R on pro-inflammatory mediators, HM-R may be considered to have anti-inflammatory activity.

\section{HM-R inhibits LPS-mediated NF-KB and MAPK signaling activation in RAW264.7 cells}

Abnormal activation of NF- $\mathrm{KB}$ and MAPK signaling in the inflammatory response results in excessive proinflammatory mediator production [11, 12]. Therefore, inhibition of NF- $\mathrm{KB}$ and MAPK signaling has been considered a major target for the development of antiinflammatory drugs [13]. Thus, we investigated the inhibitory activity of HM-R against NF- $\mathrm{kB}$ and MAPK signaling to elucidate the mechanisms associated with anti-inflammatory activity of HM-R. Degradation of IкB$\alpha$ by inflammatory stimuli such as LPS is essential for NF- $\mathrm{KB}$ signaling activation. As shown in Fig. 3a, the treatment of LPS alone induced IkB- $\alpha$ degradation, while the presence of HM-R significantly inhibited LPSmediated degradation of IkB- $\alpha$ in RAW264.7 cells. Degradation of IкB- $\alpha$ results in nuclear accumulation of $\mathrm{p} 65$, and nuclear p65 binds to genes of pro-inflammatory mediators and induces expression of pro-inflammatory mediators [14]. Thus, we investigated the inhibitory activity of HM-R on p65 nuclear accumulation. As shown in Fig. 3b, HM-R inhibited LPS-induced nuclear accumulation of $\mathrm{p} 65$. In addition, HM-R dose-dependently suppressed LPS-induce activation of NF- $\mathrm{KB}$ luciferase activity (Fig. 3c).

In the regulation of MAPK signaling pathway by HM$\mathrm{R}$, the hyper-phosphorylation of ERK1/2, p38 and JNK was observed in the cells treated with LPS alone, but HM-R dose-dependently inhibited LPS-induced phosphorylation of ERK1/2, p38 and JNK. In view of these results, it is considered that inhibition of NF- $\mathrm{KB}$ and MAPK activation is a major signaling associated with the inhibition of HM-R against the expression of proinflammatory mediators.

\section{HM-R increases HO-1 expression through ROS-dependent Nrf2 activation in RAW264.7 cells}

Recently, Heme oxygenase-1 (HO-1) has been reported as an important molecular target for anti-inflammatory activity [15] and many natural products have been reported to exhibit anti-inflammatory activity through HO-1 expression dependent on activation of NF-E2related factor 2 (Nrf2) [16-18]. Thus, we examined the effect of HM-R on HO-1 protein expression. As shown in Fig. 4a, HM-R increased the expression of HO-1 protein in a time and concentration-dependent manner. In addition, we observed that HM-R increased the nuclear accumulation of Nrf2 protein (Fig. 4b). 

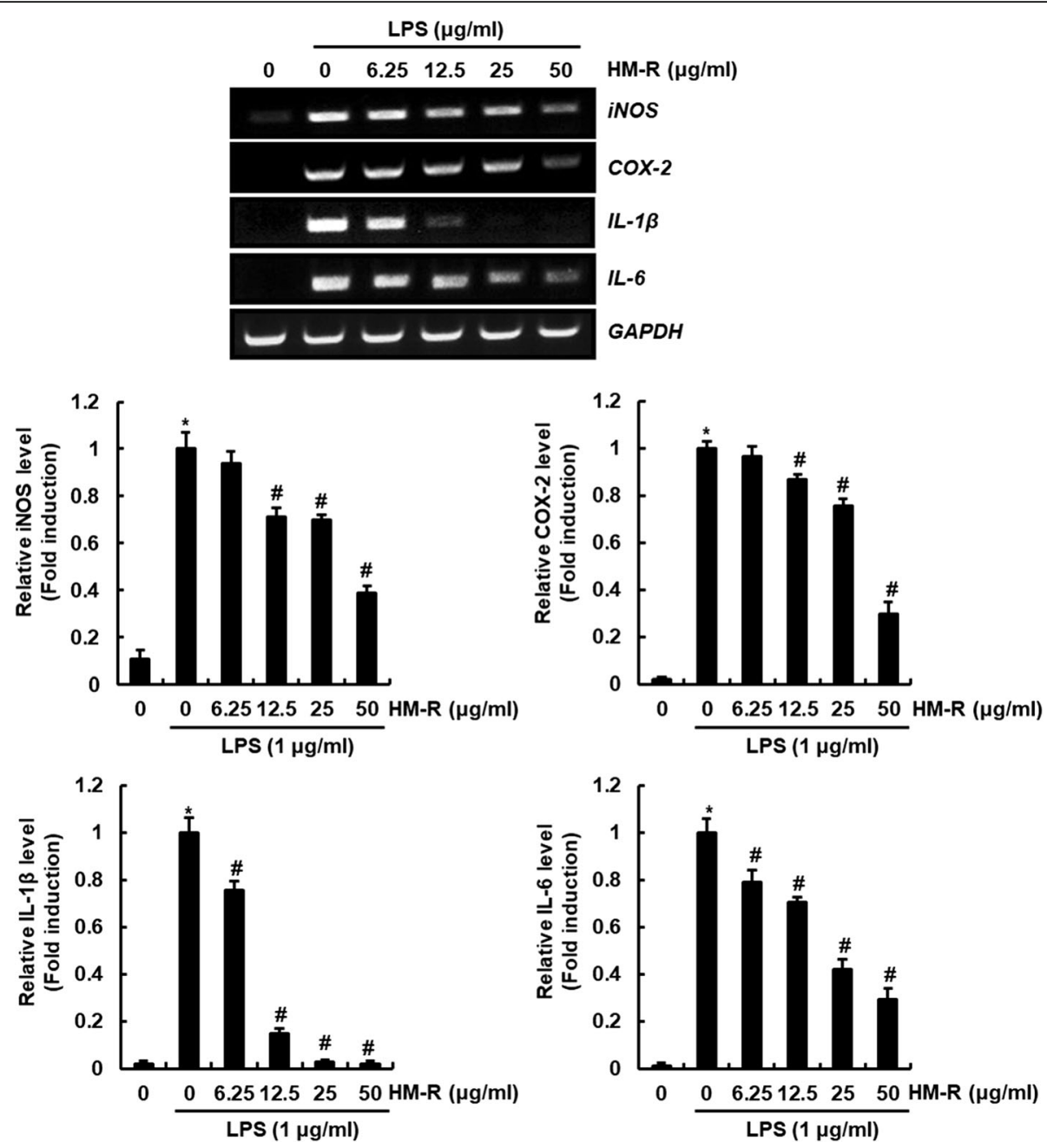

Fig. 2 Inhibitory effect of HM-R against iNOS, COX-2, IL-1 $\beta$ and IL-6 in LPS-stimulated RAW264.7 cells. RAW264.7 cells were pretreated with HM-R for $2 \mathrm{~h}$ and then co-treated with LPS $(1 \mu \mathrm{g} / \mathrm{ml})$ for $18 \mathrm{~h}$. Total RNA was prepared after LPS and HM-R treatment. GAPDH was used as internal control for RT-PCR. The density of mRNA bands was calculated using the software UN-SCAN-IT gel version 5.1 (Silk Scientific Inc. Orem, UT, USA). ${ }^{*} P<0.05$ compared to the cells without the treatment, and ${ }^{\#} P<0.05$ compared to the cells treated with LPS alone

Reactive oxygen species (ROS) has been reported to increase expression of $\mathrm{HO}-1$ protein through inducing nuclear accumulation of Nrf2 [19, 20]. In fact, Isoegomaketone as an essential oil component inhibited the production of pro-inflammatory mediators through ROS/Nrf2/HO-1 signaling activation [21]. Thus, the effect of ROS on Nrf2/ HO-1 signaling activation by HM-R was investigated. As shown in Fig. 4c, the presence of NAC (ROS scavenger) blocked HM-R-mediated increase of HO-1 and nuclear Nrf2 level. These results suggest that activation of ROS/ $\mathrm{Nrf} / \mathrm{HO}-1$ signaling is anti-inflammatory signaling of HM$\mathrm{R}$.

\section{Analysis of bioactive components}

To analyze the potential medicinal compounds with antiinflammatory activity from HM-R, we performed HPLC analysis of HM-R. As shown in Fig. 5, HM-R was analyzed to contain falcarinol (Molecular formula: $\mathrm{C}_{17} \mathrm{H}_{24} \mathrm{O}$, Molecular weight: 244.378). Indeed, HM-R was reported to have falcarinol [22]. In addition, falcarinol has been reported to exert anti-inflammatory activity [23].

\section{Discussion}

Many synthetic drugs have been developed to treat inflammatory diseases, but long-term use of such synthetic drugs is known to cause a variety of side effects such as gastric ulcer, bleeding, cardiac abnormalities, bone marrow depression, renal dysfunction and bronchospasm in long-term use [24]. Thus, there is a need to develop more effective and safe anti-inflammatory drugs [25]. In this trend, medicinal plants which have been used for the treatment of inflammatory diseases in the past, have been considered important resources for the development of traditional knowledge-based anti-inflammatory drugs [25]. 

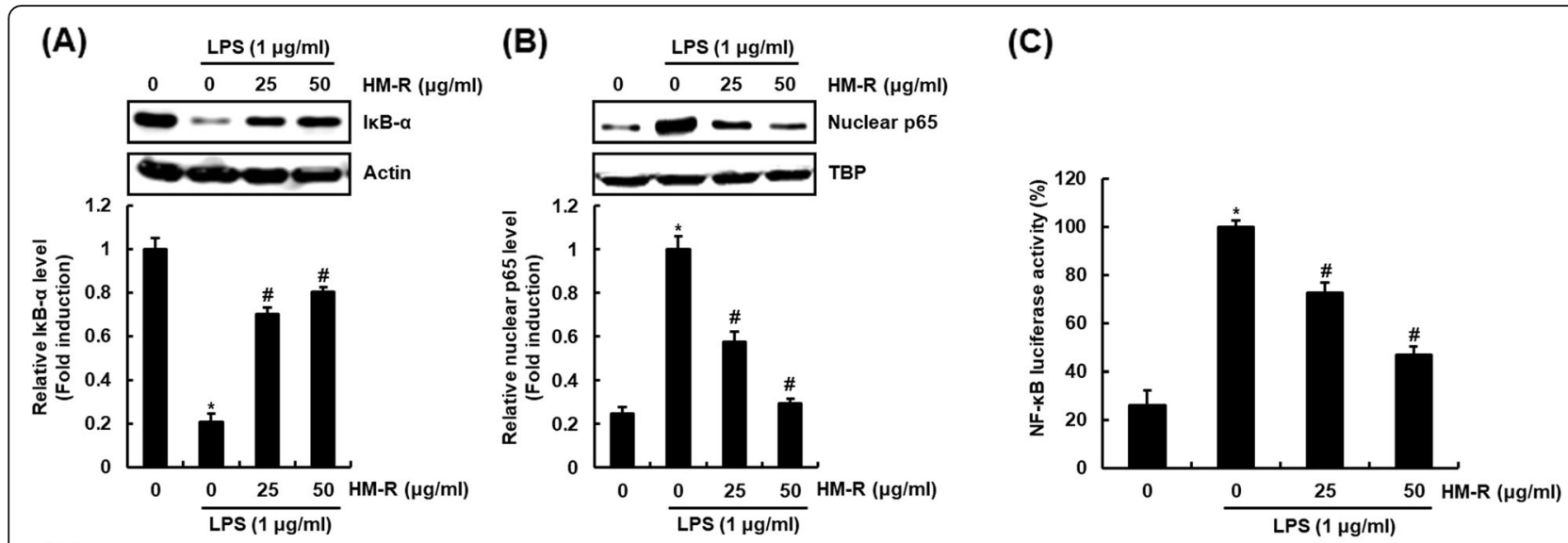

(D)
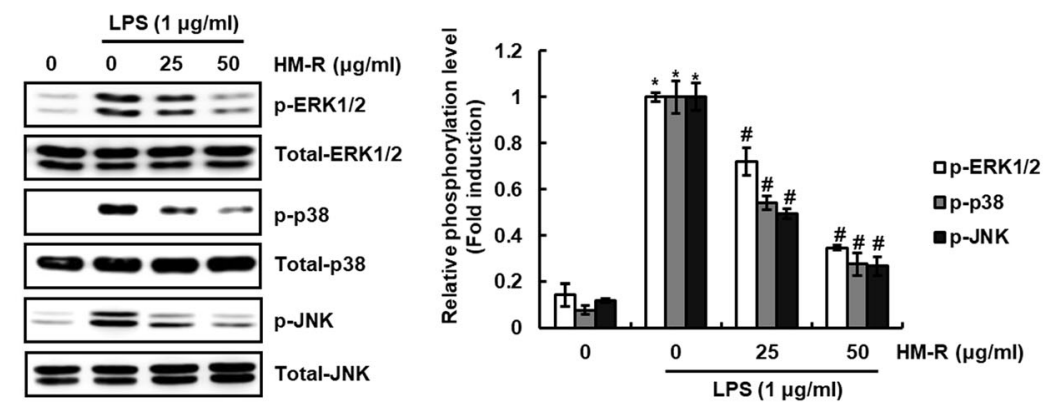

Fig. 3 Inhibitory effect of HM-R against NF-KB and MAPK signaling activation in LPS-stimulated RAW264.7 cells. a, d RAW264.7 cells were pretreated with HM-R for $2 \mathrm{~h}$ and then co-treated with LPS $(1 \mathrm{\mu g} / \mathrm{ml})$ for $20 \mathrm{~min}$. b RAW264.7 cells were pretreated with HM-R for $2 \mathrm{~h}$ and then co-treated with LPS $(1 \mathrm{\mu g} / \mathrm{ml})$ for $30 \mathrm{~min}$. After the treatment, the nucleus fraction was prepared. For Western blot analysis, the cell lysates were subjected to SDS-PAGE and the Western blot was performed using antibodies against IkB-a and p65. Actin was used as internal control for Western blot analysis. The density of Western blot bands was calculated using the software UN-SCAN-IT gel version 5.1 (Silk Scientific Inc. Orem, UT, USA). ${ }^{*} P<0.05$ compared to the cells without the treatment, and ${ }^{\#} P<0.05$ compared to the cells treated with LPS alone. c RAW264.7 cells were co-transfected with NF-KB luciferase constructs and pRL-null. The cells were pretreated with HM-R for $2 \mathrm{~h}$ and then co-treated with LPS $(1 \mathrm{\mu g} / \mathrm{ml})$ for $18 \mathrm{~h}$. Luciferase activity for NF-KB was measured as a ratio of firefly luciferase signal/renilla luciferase signal using a dual luciferase assay kit. ${ }^{*} P<0.05$ compared to the cells without the treatment, and ${ }^{\#} P<0.05$ compared to the cells treated with LPS alone

As traditional herbal medicine, Heracleum moellendorffii roots (HM-R) have traditionally been used to treat inflammatory human diseases such as arthritis, backache and fever [4]. However, the anti-inflammatory activity of $\mathrm{HM}-\mathrm{R}$ has not been scientifically investigated. In order to develop anti-inflammatory drugs using traditional knowledge about the treatment of inflammatory diseases of HM-R, scientific evidence of HM-R's anti-inflammatory activity and related mechanisms is need. Thus, we investigated anti-inflammatory activity and mechanism of action of HM-R in this study.

Although proper NO plays a major role in maintaining immunity and homeostasis, various human diseases related to inflammation are caused by excessive NO [26]. In addition, excessive $\mathrm{PGE}_{2}$ during inflammatory response is known to cause not only tissue damage, but also inflammatory diseases such as rheumatoid arthritis and chronic hepatitis [27]. In this study, we observed that HM-R blocked LPS-induced $\mathrm{NO}$ and $\mathrm{PGE}_{2}$ overproduction in RAW264.7 cells. Since NO and $\mathrm{PGE}_{2}$ are synthesized by iNOS and COX-2, respectively, the regulation of iNOS and COX-2 expression has been regarded to be important for suppression of excessive $\mathrm{NO}$ and $\mathrm{PGE}_{2}$ production [28]. Thus, the effect of HM$\mathrm{R}$ on iNOS and COX-2 expression was investigated and we observed that HM-R inhibited LPS-mediated overexpression of iNOS and COX-2, which indicating that the inhibition of iNOS and COX-2 expression by HM-R may contribute to the attenuation of $\mathrm{NO}$ and $\mathrm{PGE}_{2}$ production. In addition, appropriate pro-inflammatory cytokines such as IL- $1 \beta$ and IL- 6 contributes to the recovery of infection, but excessive accumulation of proinflammatory cytokines is known to cause chronic inflammation. Thus, the regulation of pro-inflammatory cytokines has been considered to be a complementary strategy for controlling the inflammatory disease process [2]. In this study, we observed that HM-R significantly inhibits IL-1 $\beta$ and IL-6 expression in LPS-stimulated RAW264.7 cells. These findings indicate that HM-R may exert anti-inflammatory activity. In order to confirm the degree of anti-inflammatory activity of HM-R, we compared the inhibitory effect of HM-R against LPS-induced 
(A)
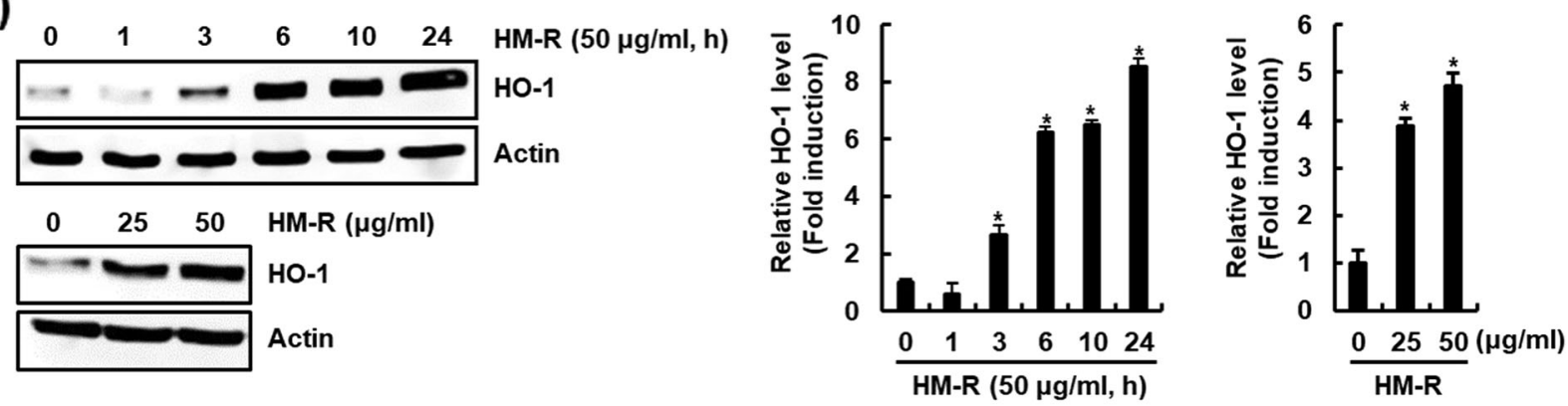

(B)
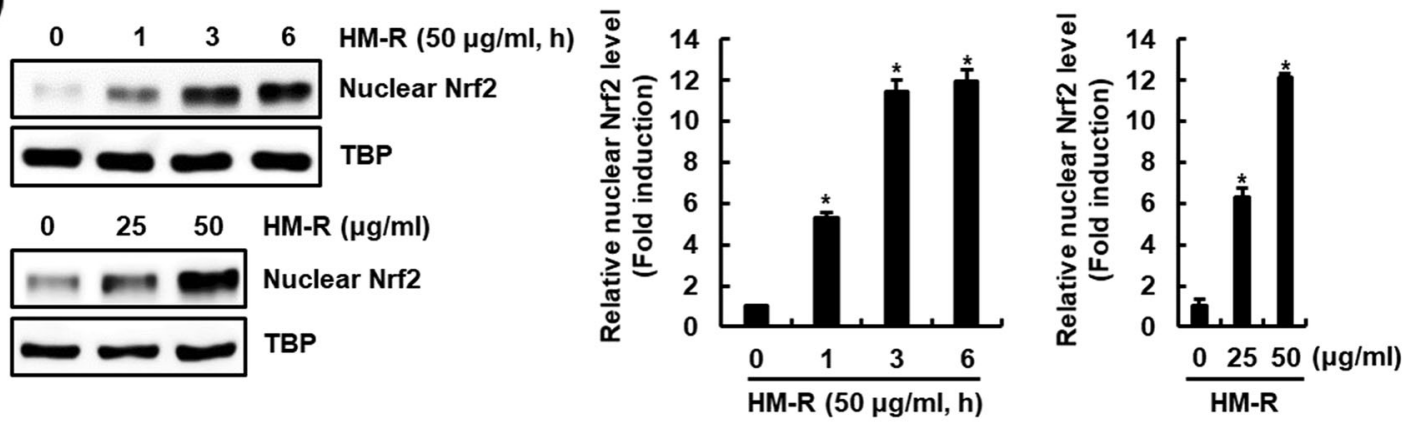

(C)
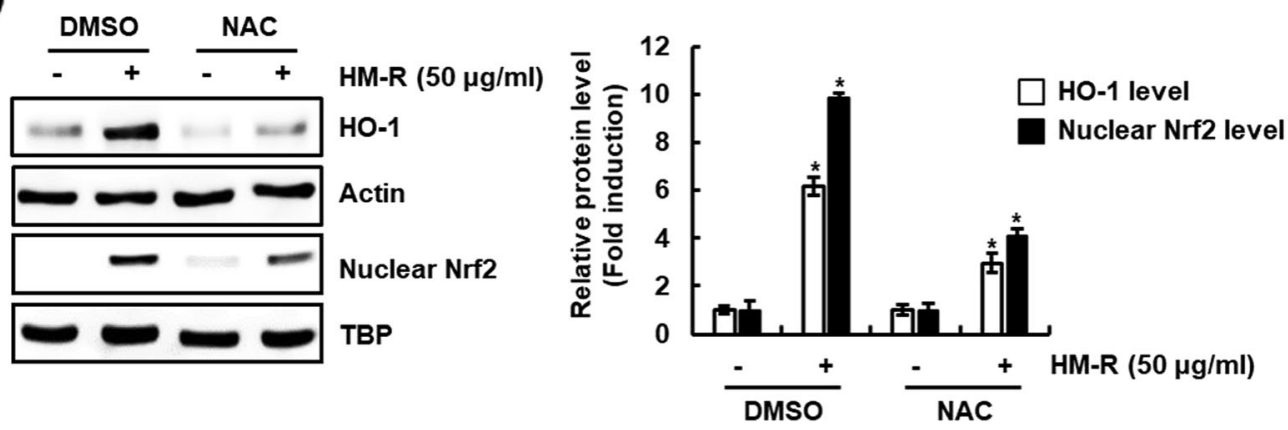

Fig. 4 Effect of HM-R on HO-1 expression through ROS-dependent Nrf2 activation. a RAW264.7 cells were treated with HM-R (50 $\mu \mathrm{g} / \mathrm{ml})$ for the indicated times or indicated concentrations for $6 \mathrm{~h}$. b RAW264.7 cells were treated with HM-R $(50 \mu \mathrm{g} / \mathrm{ml})$ for the indicated times or indicated concentrations for $3 \mathrm{~h}$. After treatment, nuclear fraction was prepared. c RAW264.7 cells were pretreated with NAC (10 mM) for $2 \mathrm{~h}$ and then cotreated with HM-R for $6 \mathrm{~h}$ for HO-1 analysis or for $3 \mathrm{~h}$ for nuclear Nrf2 anaylsis. For Western blot analysis, the cell lysates were subjected to SDSPAGE and the Western blot was performed using antibodies against HO-1 and Nrf2. Actin or TBP was used as internal control for Western blot analysis. The density of Western blot bands was calculated using the software UN-SCAN-IT gel version 5.1 (Silk Scientific Inc. Orem, UT, USA). ${ }^{*} P<$ 0.05 compared to the cells without the treatment

overproduction of NO with tolfenamic acid (TA) as one of non-steroidal anti-inflammatory drugs. At the same concentrations $(12.5 \mu \mathrm{g} / \mathrm{ml})$ of HM-R and TA, HM-R showed lower inhibitory activity against LPS-induced NO production than TA, but $25 \mu \mathrm{g} / \mathrm{ml}$ of HM-R showed similar inhibitory activity compared to TA $(12.5 \mu \mathrm{g} / \mathrm{ml})$. Although HM-R had a lower inhibitory activity against LPS-induced NO production than TA, HM-R can be considered to be a potential source for the development of anti-inflammatory drugs because HM- $\mathrm{R}$ is a crude extract.

The elucidation of mechanism for pharmacological activity is important for the development of related drugs.
LPS-induced inflammation is caused by inflammatory cascade signaling pathway, in which NF- $\mathrm{kB}$ has been known as a major transcription factor that regulates that production of pro-inflammatory mediators [29, 30]. Under inflammatory stimuli, NF- $\mathrm{kB}$ activation occurs through the phosphorylation and degradation of IкB- $\alpha$, and subsequent p65 nuclear translocation. Nuclear p65 activates transcription of pro-inflammatory mediators $[29,30]$. Consequently, HM-R blocked LPS-induced degradation of $\mathrm{I} \kappa \mathrm{B}-\alpha$ and nuclear accumulation of $\mathrm{p} 65$, which resulted in the suppression of NF- $\mathrm{kB}$ activation. Similar to NF-kB signaling, LPS-activated MAPKs such 


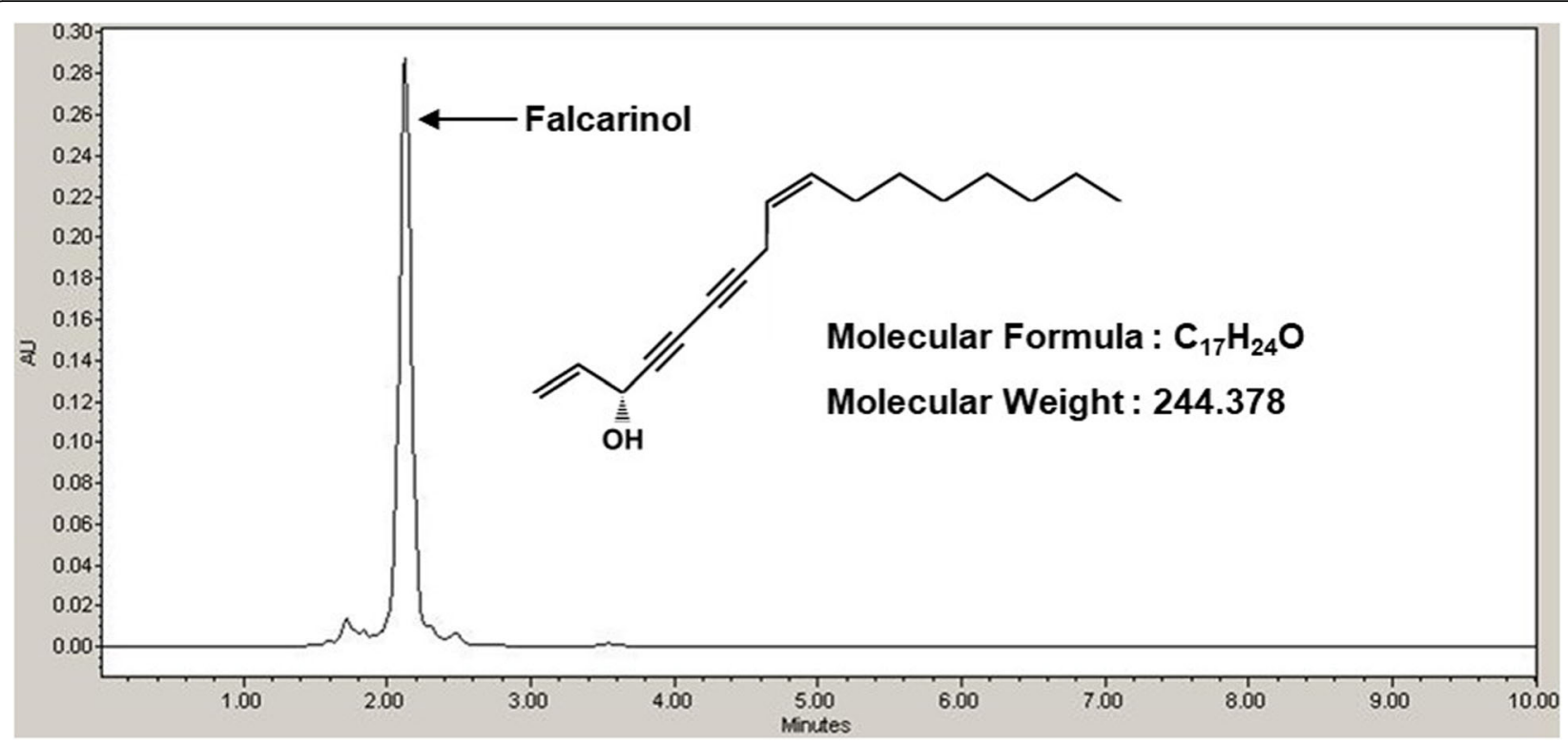

Fig. 5 Chromatography of HPLC analysis of HM-R

as ERK1/2, p38 and JNK also play an important role in the generation of pro-inflammatory mediators $[29,31]$. Furthermore, it has been known that MAPK is crucial for NF- $\mathrm{KB}$ activation and the binding of NF- $\mathrm{KB}$ to proinflammatory genes [32, 33]. In this study, HM-R significantly decreased the phosphorylation of ERK1/2, p38 and JNK. These findings indicate that HM-R may exert anti-inflammatory activity through the inhibition of NF$\mathrm{KB}$ and MAPK signaling activation.

It is known that heme oxygenase-1 (HO-1), which catalyzes the degradation of heme into biliverdin, iron and carbon monoxide has anti-oxidant, anti-inflammatory and anti-proliferative functions [34, 35]. In fact, the antiinflammatory activity of $\mathrm{HO}-1$ has been demonstrated by various studies. It has been reported that overexpression of HO-1 prior to inflammatory stimulation inhibited expression of inflammatory mediators such as $\mathrm{NO}$ and IL-6 [36, 37]. In addition, severe inflammation appeared in mice model deficient in HO-1 [38]. These previous experimental evidence suggest that $\mathrm{HO}-1$ may be a potential molecular target for treating inflammation [21]. NF-E2-related factor 2 (Nrf2), known as the upstream mediator of $\mathrm{HO}-1$, is present in the cytoplasm under unstressed condition, while accumulated nuclear Nrf2 under the oxidative stress causes the expression of HO-1 [39]. In this study, we confirmed that nuclear accumulation of Nrf2 and HO-1 expression were increased in HM-R treated RAW264.7 cells. We also found that nuclear accumulation of Nrf2 and the increased expression of HO-1 by HM-R were reduced in NAC-treated RAW264.7 cells. These results indicate that HM-R may induce HO-1 expression through ROS-dependent Nrf2 activation, which contributes to anti-inflammatory activity.

In the analysis of anti-inflammatory compounds from HM-R using HPLC, falcarinol (Molecular formula: $\mathrm{C}_{17} \mathrm{H}_{24} \mathrm{O}$, Molecular weight: 244.378) also known as panaxynol was analyzed. The previous study has reported that HM-R contains falcarinol [22]. In addition, falcarinol was reported to exert anti-inflammatory effect through $\mathrm{Nrf} 2 / \mathrm{HO}-1$ signaling activation [23].

\section{Conclusion}

Taken together, these results show that HM-R inhibits the expression of pro-inflammatory mediators and cytokines through suppressing the NF- $\mathrm{kB}$ and MAPK signaling, and activating ROS/Nrf2/HO-1 signaling. These results can provide scientific evidence of traditional knowledge about the treatment of inflammatory diseases using HM-R. In addition, based on traditional knowledge, HM-R can be used as a resource for the development of anti-inflammatory drugs.

\section{Abbreviations}

COX-2: cyclooxygenase-2; HM-R: Heracleum moellendorffii; HO-1: Heme oxygenase-1; IL-1 $\beta$ : Interleukin-1 $\beta$; IL-6: Interleukin-6; iNOS: Inducible nitric oxide synthase; LPS: Lipopolysaccharide; MAPK: Mitogen-activated protein kinase; MTT: 3-(4,5-dimethylthiazol-2-yl)-2,5-diphenyltetrazolium bromide; NFKB: Nuclear factor-kappaB; NO: Nitric oxide; Nrf2: Nuclear factor erythroid 2related factor 2; $\mathrm{PGE}_{2}$ : prostaglandin $\mathrm{E}_{2}$ 


\section{Authors' contributions}

JBJ directed and designed the study. HNK, JDK, JHY, HJS, SBP, GHP and HJE performed the experiments. JHY and JDK analyzed the medicinal compounds with anti-inflammatory activity from HM-R. HNK and JDK drafted manuscript. JBJ corrected the manuscript. All authors read and approved the final manuscript.

\section{Funding}

This work was supported by Basic Science Research Program through the National Research Foundation of Korea (NRF) funded by the Ministry of Education (NRF-2016R1D1A3B03931713 and NRF-2018R1A6A1A03024862). Two funding bodies provided financial support for this study. The founding sponsor had no role in the study design, performance, data collection and analysis, decision to publish, or preparation/writing of the manuscript.

\section{Availability of data and materials}

The datasets used and/or analyzed during the current study available from the corresponding author on reasonable request.

\section{Ethics approval and consent to participate}

Not applicable.

\section{Consent for publication}

Not applicable.

\section{Competing interests}

The authors declare that they have no competing interests and JBJ as a member of the editorial board (associate editor) of this journal ensure transparency.

\section{Author details}

'Department of Medicinal Plant Resources, Andong National University, Andong 36729, Republic of Korea. ${ }^{2}$ Forest Medicinal Resources Research Center, National Institute of Forest Science, Yongju 36040, Republic of Korea. ${ }^{3}$ Insititute of Agricultural Science and Technology, Andong National University, Andong 36729, Republic of Korea.

Received: 5 September 2019 Accepted: 31 October 2019 Published online: 12 November 2019

\section{References}

1. Abarikwu SO. Kolaviron, a natural flavonoid from the seeds of Garcinia kola, reduces LPS-induced inflammation in macrophages by combined inhibition of IL-6 secretion, and inflammatory transcription factors, ERK1/2, NF-kappaB, p38, Akt, p-c-JUN and JNK. Biochim Biophys Acta. 2014;1840(7):2373-81.

2. Nguyen PH, Zhao BT, Lee JH, Kim YH, Min BS, Woo MH. Isolation of benzoic and cinnamic acid derivatives from the grains of Sorghum bicolor and their inhibition of lipopolysaccharide-induced nitric oxide production in RAW 264.7 cells. Food Chem. 2015;168:512-9.

3. Wen ZS, Xiang XW, Jin HX, Guo XY, Liu LJ, Huang YN, OuYang XK, Qu YL. Composition and anti-inflammatory effect of polysaccharides from Sargassum horneri in RAW264.7 macrophages. Int. J Biol Macromol. 2016;88:403-13.

4. Alam MB, Seo BJ, Zhao P, Lee SH. Anti-Melanogenic activities of Heracleum moellendorffii via ERK1/2-mediated MITF Downregulation. Int J Mol Sci. 2016; 17(11):E1844.

5. Bang JE, Choi HY, Kim SI. Anti-oxidative activity and chemical composition of various Heracleum moellendorffii Hance extracts. Korean J Food Preserv. 2009;16:765-71.

6. Park HJ, Nugroho A, Jung B, Won YH, Jung YJ, Kim WB, Choi JS. Isolation and quantitative analysis of flavonoids with peroxynitrite-scavenging effect from the young leaves of Heracleum moellendorffii. Korean J. Plant Res. 2010; 23:393-8.

7. Bae DS, Kim CY, Lee JK. Anti-inflammatory effects of dehydrogeijerin in LPSstimulated murine macrophages. Int Immunopharmacol. 2012;14(4):734-9.

8. Williams CS, Mann M, DuBois RN. The role of cyclooxygenases in inflammation, cancer, and development. Oncogene. 1999;18(55):7908-16.

9. Sampey AV, Monrad S, Crofford L. Microsomal prostaglandin E synthase-1: the inducible synthase for prostaglandin E2. Arthritis Res Ther. 2005;7(3):114-7.
10. Fujiwara N, Kobayashi K. Macrophages in inflammation. Curr Drug Targets Inflamm Allergy. 2005;4(3):281-6.

11. DiDonato JA, Mercurio F, Karin M. NF-kappaB and the link between inflammation and cancer. Immunol Rev. 2012;246(1):379-400.

12. Liu Y, Shepherd EG, Nelin LD. MAPK phosphatases--regulating the immune response. Nat Rev Immunol. 2007;7(3):202-12

13. Luo JF, Shen XY, Lio CK, Dai Y, Cheng CS, Liu JX, Yao YD, Yu Y, Xie Y, Luo P, Yao XS, Liu ZQ, Zhou H. Activation of Nrf2/HO-1 pathway by Nardochinoid $C$ inhibits inflammation and oxidative stress in lipopolysaccharidestimulated macrophages. Front Pharmacol. 2018;9:911.

14. Ghosh S, May MJ, Kopp EB. NF-kappa B and Rel proteins: evolutionarily conserved mediators of immune responses. Annu Rev Immunol. 1998; 16:225-60.

15. Poss KD, Tonegawa S. Reduced stress defense in heme oxygenase 1deficient cells. Proc Natl Acad Sci U S A. 1997;94(20):10925-30.

16. Hu CM, Liu YH, Cheah KP, Li JS, Lam CS, Yu WY, Choy CS. Heme oxygenase1 mediates the inhibitory actions of brazilin in RAW264.7 macrophages stimulated with lipopolysaccharide. J. Ethnopharmacol. 2009;121(1):79-85.

17. Jun MS, Ha YM, Kim HS, Jang HJ, Kim YM, Lee YS, Kim HJ, Seo HG, Lee JH, Lee SH, Chang KC. Anti-inflammatory action of methanol extract of Carthamus tinctorius involves in heme oxygenase-1 induction. J Ethnopharmacol. 2011;133(2):524-30.

18. Lee DS, Jeong GS, Li B, Park H, Kim YC. Anti-inflammatory effects of sulfuretin from Rhus verniciflua Stokes via the induction of heme oxygenase-1 expression in murine macrophages. Int Immunopharmacol. 2010;10(8):850-8

19. Alam J, Cook JL. Transcriptional regulation of the heme oxygenase-1 gene via the stress response element pathway. Curr Pharm Des. 2003;9(30):2499-511.

20. Liu XM, Peyton KI, Shebib AR, Wang H, Durante W. Compound C stimulates heme oxygenase-1 gene expression via the Nrf2-ARE pathway to preserve human endothelial cell survival. Biochem Pharmacol. 2011;82(4):371-9.

21. Jin CH, So YK, Han SN, Kim JB. Isoegomaketone Upregulates Heme Oxygenase-1 in RAW264.7 cells via ROS/p38 MAPK/Nrf2 pathway. Biomol Ther. 2016;24(5):510-6.

22. Nakano $Y$, Matsunaga $H$, Saita $T$, Mori M, Katano M, Okabe $H$. Antiproliferative constituents in Umbelliferae plants II. Screening for polyacetylenes in some Umbelliferae plants, and isolation of panaxynol and falcarindiol from the root of Heracleum moellendorffii. Biol. Pharm. Bull. 1998: 21(3):257-61.

23. Stefanson AL, Bakovic M. Falcarinol is a potent inducer of heme oxygenase1 and was more effective than sulforaphane in attenuating intestinal inflammation at diet-achievable doses. Oxidative Med Cell Longev. 2018; 2018:1-14.

24. Hawkey CJ, Langman MJ. Non-steroidal anti-inflammatory drugs: overall risks and management. Complementary roles for COX-2 inhibitors and proton pump inhibitors. Gut. 2003;52(4):600-8.

25. Syama HP, Sithara T, Lekshmy Krishnan S, Jayamurthy P. Syzygium cumini seed attenuates LPS induced inflammatory response in murine macrophage cell line RAW264.7 through NF-kB translocation. J Funct Foods. 2018;44:218-26.

26. Zou YH, Zhao L, Xu YK, Bao JM, Liu X, Zhang JS, Li W, Ahmed A, Yin S, Tang $\mathrm{GH}$. Anti-inflammatory sesquiterpenoids from the Traditional Chinese Medicine Salvia plebeia: Regulates pro-inflammatory mediators through inhibition of NF-kappaB and Erk1/2 signaling pathways in LPS-induced Raw264.7 cells. J. Ethnopharmacol. 2018;210:95-106.

27. Dang K, Lamb K, Cohen M, Bielefeldt K, Gebhart GF. Cyclophosphamideinduced bladder inflammation sensitizes and enhances P2X receptor function in rat bladder sensory neurons. J Neurophysiol. 2008;99(1):49-59.

28. Ardizzone S, Bianchi PG. Biologic therapy for inflammatory bowel disease. Drugs. 2005;65(16):2253-86.

29. Gantke T, Sriskantharajah S, Sadowski M, Ley SC. IKB kinase regulation of the TPL-2/ERK MAPK pathway. Immunol Rev. 2012;246(1):168-82.

30. Guha M, Mackman N. LPS induction of gene expression in human monocytes. Cell Signal. 2001;13(2):85-94.

31. Arthur JS, Ley SC. Mitogen-activated protein kinases in innate immunity Nat. Rev. Immunol. 2013;13(9):679-92.

32. Olson CM, Hedrick MN, Izadi H, Bates TC, Olivera ER, Anguita J. p38 mitogen-activated protein kinase controls NF-kappaB transcriptional activation and tumor necrosis factor alpha production through RelA phosphorylation mediated by mitogen- and stress-activated protein kinase 1 in response to Borrelia burgdorferi antigens. Infect Immun. 2007;75(1):270-7. 
33. Reber L, Vermeulen L, Haegeman G, Frossard N. Ser276 phosphorylation of NF-kB p65 by MSK1 controls SCF expression in inflammation. PLoS One. 2009;4(2):e4393.

34. Yamada N, Yamaya M, Okinaga S, Nakayama K, Sekizawa K, Shibahara S, Sasaki H. Microsatellite polymorphism in the heme oxygenase-1 gene promoter is associated with susceptibility to emphysema. Am J Hum Genet 2000;66(1):187-95

35. Gabunia K, Ellison SP, Singh H, Datta P, Kelemen SE, Rizzo V, Autieri MV. Interleukin-19 (IL-19) induces heme oxygenase-1 (HO-1) expression and decreases reactive oxygen species in human vascular smooth muscle cells. $J$ Biol Chem. 2012;287(4):2477-84.

36. Park PH, Kim HS, Jin XY, Jin F, Hur J, Ko G, Sohn DH. KB-34, a newly synthesized chalcone derivative, inhibits lipopolysaccharide-stimulated nitric oxide production in RAW 264.7 macrophages via heme oxygenase-1 induction and blockade of activator protein-1. Eur J Pharmacol. 2009;606(13):215-24

37. Jin CH, Lee HJ, Park YD, Choi DS, Kim DS, Kang SY, Seo Kl, Jeong IY. Isoegomaketone inhibits lipopolysaccharide-induced nitric oxide production in RAW 264.7 macrophages through the heme oxygenase-1 induction and inhibition of the interferon-beta-STAT-1 pathway. J Agric Food Chem. 2010; 58(2):860-7.

38. True AL, Olive M, Boehm M, San H, Westrick RJ, Raghavachari N, Xu X, Lynn EG, Sack MN, Munson PJ, Gladwin MT, Nabel EG. Heme oxygenase-1 deficiency accelerates formation of arterial thrombosis through oxidative damage to the endothelium, which is rescued by inhaled carbon monoxide. Circ Res. 2007:101(9):893-901.

39. Kaspar JW, Niture SK, Jaiswal AK. Nrf2:INrf2 (Keap1) signaling in oxidative stress. Free Radic Biol Med. 2009:47(9):1304-9.

\section{Publisher's Note}

Springer Nature remains neutral with regard to jurisdictional claims in published maps and institutional affiliations.

Ready to submit your research? Choose BMC and benefit from:

- fast, convenient online submission

- thorough peer review by experienced researchers in your field

- rapid publication on acceptance

- support for research data, including large and complex data types

- gold Open Access which fosters wider collaboration and increased citations

- maximum visibility for your research: over $100 \mathrm{M}$ website views per year

At $\mathrm{BMC}$, research is always in progress.

Learn more biomedcentral.com/submissions 